\title{
STRATEGI PENGEMBANGAN WISATA DI SITU PENGASINAN KOTA DEPOK
}

\author{
Strategies for Tourismn Development in Situ Pangasinan Depok
}

Diah Pusporini 1, Dedi Budiman Hakim 2, dan Sutara Hendrakusumaatmadja ${ }^{3}$

\author{
1 Staff Badan Lingkungan Hidup Kota Depok. E-mail: mpdipb@hotmail.com \\ 2 Staff Pengajar Departemen Ilmu Ekonomi. Fakultas Ekonomi dan Manajemen IPB. \\ E-mail: dedihakim@gmail.com,
}
3 Staff Pengajar Departemen Ekonomi Sumberdaya dan Lingkungan. Fakultas Ekonomi dan Manajemen IPB. E-mail: shkipb@gmail.com

\begin{abstract}
Tourism destinations in Depok have not yet been integrated. Thus, tourism site with a concept of one stop recreation area need to be created and developed. By creating two scenarios, those are free and charged area, Situ Pengasinan is selected for its beauty and location. The purpose of the assessment is to find the perception of the community on tourism development, investement cost, the Willingness to Pay, investement suitability as well as the strategies need to be applied in the development. The result shows that most participants agree on the development plan. Financial analysis result says that the building of infrastructure and tourist attractions cost Rp 6,045 billion. Most of 51 percent of participants is willing to spend if it is charged with the amount of WTP value is $R p$ 7.309,52 per person. The development is also financially proper. The assessment results in several development strategies those are socialization, empowering the community, investor, infrastructure, and also institutional policy or support.
\end{abstract}

Keywords: Financial Analysis, Tourism Development, Willingness to Pay

\begin{abstract}
ABSTRAK
Belum terintegrasinya destinasi wisata di Kota Depok mendorong perlu dilakukannya pengembangan wisata dengan konsep one stop recreation. Dengan dua pilihan skenario, yaitu tanpa dan dengan pemberlakuan tarif, Situ Pengasinan dipilih sebagai lokasi pengembangan karena keindahan serta lokasinya. Kajian ini bertujuan untuk mengetahui persepsi masyarakat terhadap pengembangan wisata di Situ Pengasinan, besarnya nilai investasi yang dibutuhkan, kesediaan masyarakat (Willingness to Pay), kelayakan investasi kegiatan pengembangan, dan strategi pengembangan wisata di Situ Pengasinan. Metode yang digunakan dalam penelitian ini adalah regresi logistik, regresi linier, analisis finansial, dan Analytical Hierrachy Proccess (AHP). Hasil kajian menunjukkan persepsi responden yang menyambut baik rencana pengembangan. Hasil analisis finansial memperlihatkan bahwa diperlukan investasi sebesar $\mathrm{Rp}$ 6,045 milyar untuk pembangunan sarana prasarana dan atraksi wisata. Sebanyak 51 persen responden bersedia membayar Rp 7.309,52 per orang jika diterapkan skenario pemberlakuan tarif. Hasil analisis kelayakan investasi menunjukkan bahwa kegiatan pengembangan layak dilakukan. Beberapa strategi pengembangan wisata yang dihasilkan meliputi strategi sosialisasi, strategi pemberdayaan masyarakat, strategi peningkatan tingkat pendapatan secara ekonomi, strategi investor, strategi infrastruktur, serta strategi kebijakan/dukungan kelembagaan.
\end{abstract}

Kata kunci: Analisis Finansial, Pengembangan Wisata, Kesediaan untuk Membayar

\section{PENDAHULUAN}

\section{Latar Belakang}

Fenomena otonomi daerah sedikit banyak memberi pengaruh yang cukup besar terhadap sumber-sumber penerimaan daerah, khususnya Pendapatan Asli Daerah (PAD). Daerah-daerah minus potensi sumberdaya alam memiliki kesempatan untuk menambah marjin penerimaan dari sektor lain seperti pariwisata. Dengan demikian, pengembangan pariwisata di daerah miskin SDA dapat menjadi 
alternatif sumber penerimaan daerah. Menurut Yoeti (1999), sektor pariwisata masih dianggap sebagai sektor yang potensial di masa yang akan datang.

Sejak tahun 1999 Kota Depok resmi menjadi daerah otonom (UU No. 15 tahun 1999 tentang Pembentukkan Kotamadya Daerah Tingkat II Cilegon dan Kotamadya Tingkat II Depok). Pembangunan Kota Depok selanjutnya diarahkan sebagai kota penyeimbang ibukota (buffer zone) dan termasuk di dalamnya adalah pembangunan dan pengembangan sektor pariwisata. Sebagai salah satu penyumbang pendapatan daerah, sektor pariwisata masih menyimpan beragam potensi untuk dikembangkan lebih lanjut. Berdasarkan Rencana Strategis (Renstra) 2006-2011 Kantor Pariwisata Seni dan Budaya Kota Depok, pengembangan kawasan wisata di Kota Depok direncanakan melalui pemanfaatan sumberdaya alam seperti Situ yang tersebar di dalam kota, Daerah Aliran Sungai (DAS) Ciliwung dan Taman Hutan Raya Pancoran Mas (Kantor Pariwisata Seni dan Budaya Kota Depok, 2006).

Situ Pengasinan sebagai bagian dari Bagian Wilayah Kota Sawangan dan Kawasan Siap Bangun (Kasiba) atau Lingkungan Siap Bangun (Lisiba) Sawangan dengan luasan 6,5 ha akan dikembangkan menjadi Ruang Terbuka Hijau (RTH) alami perlindungan setempat terhadap fungsi konservasi Situ Pengasinan. Konsep pengembangan fungsi di sekitar kawasan Situ Pengasinan pun didorong untuk menunjang kegiatan sekitar danau, diantaranya kegiatan wisata alam, perikanan, dan agro wisata. Dengan melihat potensi sumberdaya alam dan peluang pengembangan wisata yang cukup menjanjikan, maka konsep one stop recreation yang akan dikembangkan di Situ Pengasinan diharapkan dapat menjadi role model pengembangan wisata sejenis di Kota Depok. Untuk itu perlu dilakukan kajian mengenai strategi pengembangan wisata di Situ Pengasinan Kota Depok.

\section{Perumusan Masalah}

Pola pengembangan daerah objek wisata di Kota Depok belum terintegrasi dalam satu konsep one stop recreation (Gambar 1) sehingga pengunjung harus mendatangi tempat-tempat wisata yang jaraknya saling berjauhan. Namun langkanya destinasi wisata Kota Depok menyebabkan rencana pengembangan wisata di Situ Pengasinan berpotensi cukup bagus. Untuk itu dibutuhkan informasi mengenai persepsi pengunjung Situ Pengasinan terkait rencana pengembangan situ sebagai kawasan one stop recreation di Kota Depok demi kelancaran prosesnya. Pengembangan suatu kawasan dalam rangka memenuhi kebutuhan masyarakat merupakan tanggungjawab Pemerintah Daerah. Namun pemerintah seringkali bekerjasama dengan pihak swasta karena keterbatasan APBD. Untuk itu dibutuhkan analisa mengenai jumlah investasi yang dibutuhkan dalam rangka pengembangan kegiatan tersebut. Selain itu, adanya rencana penerapan skenario pemberlakuan tarif masuk kawasan wisata menjadikan dibutuhkannya informasi mengenai berapa besar kesediaan pengunjung untuk membayar (willingness to pay) serta apa saja faktor-faktor yang mempengaruhi besarnya WTP tersebut.

Dalam kaitannya dengan konsep pengembangan wisata berbasis konservasi serta ekonomi lokal yang memihak masyarakat, dibutuhkan kriteria kelayakan finansial dari rencana kegiatan, dalam hal ini yaitu rencana pengembangan Situ Pengasinan. Selanjutnya juga perlu dibentuk rumusan strategi dan perancangan program pengembangan Situ Pengasinan sebagai kawasan one stop recreation di Kota Depok. 


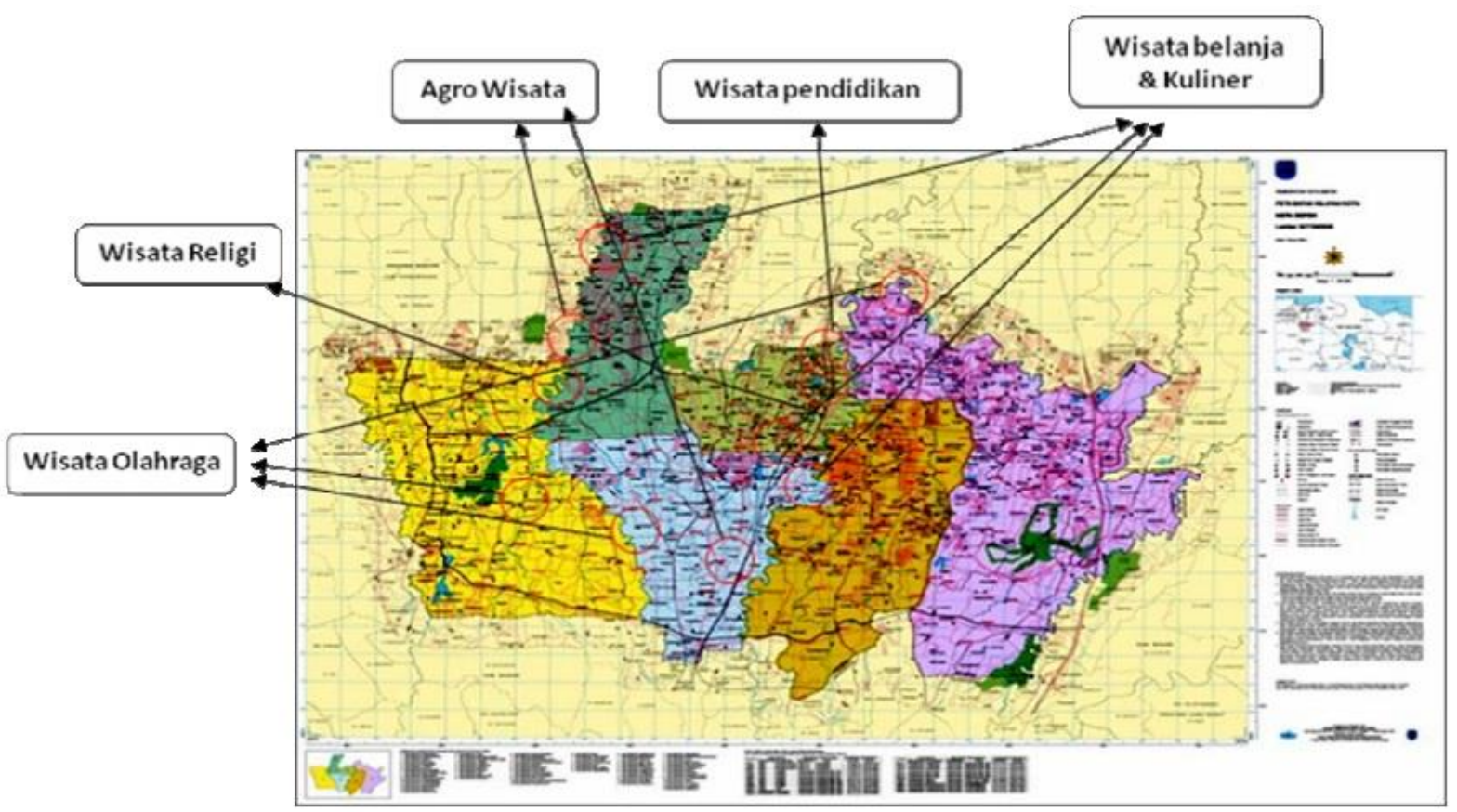

Gambar 1. Peta Daerah Objek Wisata di Kota Depok

\section{Tujuan Penelitian}

Tujuan yang ingin dicapai dalam kajian ini, antara lain:

1. Menganalisis persepsi pengunjung kawasan Situ Pengasinan terhadap pengembangan situ

2. Menganalisis besarnya investasi yang dibutuhkan serta biaya yang akan dikeluarkan dalam pengembangan wisata

3. Menganalisis kesediaan masyarakat untuk membayar (willingness to pay) jika nantinya dikenakan tarif masuk kawasan berikut faktor-faktor yang mempengaruhi besarnya WTP tersebut

4. Menganalisis kelayakan investasi dari pengembangan wisata yang akan dilaksanakan

5. Menyusun strategi dan rancangan program pengembangan Situ Pengasinan sebagai kawasan one stop recreation di Kota Depok.

\section{TINJAUAN PUSTAKA}

\section{Pengembangan Pariwisata Alam}

Karyono (1997) menyatakan bahwa pariwisata adalah seluruh kegiatan pemerintah, dunia usaha dan masyarakat untuk mengatur, mengurus, dan melayani kebutuhan wisatawan. Sedangkan menurut Undang-undang Nomor 9 tahun 1990, pariwisata adalah segala sesuatu yang berhubungan dengan wisata, termasuk pengusahaan-pengusahaan objek dan daya tarik wisata beserta usaha-usaha yang terkait dibidang tersebut.

Pengembangan pariwisata suatu daerah dipengaruhi oleh kondisi alam dan kekhasan budaya yang dimiliki. Pariwisata merupakan komoditi prospektif yang mempunyai peranan penting dalam pembangunan suatu daerah. Menurut Dahuri (2003), salah satu tipologi pariwisata yang menjadi alternatif adalah kegiatan ekoturisme (wisata alam) yang mengandalkan keindahan alam. Dari dimensi ekologis, kegiatan ini jelas mengandalkan keindahan alam sehingga kegiatan ini akan mendorong tindakan konservasi untuk mempertahankan daya tariknya agar keuntungan dari kegiatan 
wisata tersebut dapat dipertahankan. Sementara itu aspek sosial masyarakat setempat dimana kegiatan ekoturisme ini berlangsung sering mendapat manfaat ekonomi dari pengembangan kegiatan jasa pendukung wisata dan gangguan terhadap kehidupan masyarakat umumnya sangat kecil.

Sehubungan dengan penerapan otonomi daerah maka segala sesuatu yang menyangkut pengembangan pariwisata yang meliputi pembiayaan, perijinan, perencanaan, dan evaluasi menjadi wewenang daerah untuk menyelenggarakannya. Dengan demikian masing-masing daerah dituntut untuk lebih mandiri dalam mengembangkan objek dan potensi wisatanya termasuk pembiayaan promosinya. Pengembangan pariwisata merupakan bagian dari pembangunan suatu daerah dalam konteks pembangunan berkelanjutan yang diarahkan untuk memenuhi kebutuhan akan rekreasi. Menurut Dahuri dkk. (1996), garis besar konsep pembangunan berkelanjutan mempunyai empat dimensi, yaitu dimensi ekologis, sosial ekonomi, sosial politik, serta hukum dan kelembagaan.

Pengembangan pariwisata suatu daerah juga berkaitan erat dengan pembangunan perekonomian daerah tersebut. Dampak positif yang secara langsung dapat dirasakan oleh masyarakat setempat adalah adanya perluasan lapangan kerja secara regional. Konsep pengembangan pariwisata yang tidak hanya terpaku pada satu objek untuk satu wilayah, melainkan antar wilayah. Pengembangan pola distribusinya tidak lagi melihat batasan geografis. Gagasan tersebut memberikan angin segar bagi pengembangan pariwisata terlebih dengan telah diterapkannya otonomi daerah. Paling tidak kebijakan baru tersebut dapat digunakan untuk mengembangkan dan mendayagunakan potensi-potensi wisata daerah melalui kerjasama antar daerah. Namun penerapan program kerjasama tersebut jangan sampai memicu konflik yang justru berdampak merugikan, sehingga tujuan dan pengembangan pariwisata daerah menjadi tidak tercapai. Saifullah (2000) mengatakan bahwa pengembangan pariwisata menimbulkan manfaat dibeberapa bidang, yaitu bidang ekonomi, salah satunya untuk menunjang pembangunan daerah, bidang sosial budaya serta bidang lingkungan hidup.

Pariwisata alam di tengah kota umumnya dilakukan di danau atau situ. Situ menurut Suryadiputra (2005) dapat dikategorikan sebagai salah satu jenis lahan basah (umumnya berair tawar) dengan sistem perairan yang tergenang. Fungsi situ secara umum adalah daerah konservasi sumberdaya air serta pengatur iklim mikro bagi daerah sekitar. Fungsi lainnya situ dapat dimanfaatkan sebagai irigasi, perikanan dan rekreasi. Manfaat situ secara ekologis adalah sebagai sistem penyerapan dan tandon air serta keberlangsungan proses ekologis didalamnya. Manfaat sosioekonomi antara lain sebagai cadangan sumber air bersih, pengendali banjir, irigasi, sumber penyedia protein dari sektor perikanan darat, dan sebagainya. Situ yang terbentuk dari proses alami biasanya digunakan sebagai sumber air bersih, irigasi pertanian, perikanan budidaya dan non budidaya/tangkap, dan wisata air.

\section{Penilaian Jasa Lingkungan}

Penilaian keuntungan dari perubahan lingkungan sangat kompleks. Menurut Yakin (1997), terlepas dari keuntungan yang dinikmati oleh pengguna langsung jasa lingkungan, non users juga dapat memperoleh keuntungan dari penyediaan barang lingkungan tersebut. Salah satu alat yang digunakan dalam penilaian jasa lingkungan adalah willingness to pay (WTP) yang merupakan suatu studi yang digunakan untuk mengukur tingkat kemauan (willingness) masyarakat dalam membayar atau mengeluarkan sejumlah uang untuk memperoleh sejumlah barang atau jasa. Menurut Hanley dan Splash (1993) dalam Putri dkk. (2007), dalam WTP dihitung seberapa jauh kemampuan setiap individu 
atau masyarakat secara agregat untuk membayar atau mengeluarkan uang dalam rangka memperbaiki kondisi lingkungan agar sesuai dengan standar yang diinginkan.

Menurut Dewi (2004) konsep WTP dapat mencerminkan nilai yang dianut oleh seorang individu dan juga dapat mencerminkan perilakunya. Asumsinya adalah bahwa setiap individu atau rumahtangga akan membuat keputusan secara rasional dalam menggunakan sumberdaya yang dimilikinya. WTP juga terkait dengan informasi atau tingkat pengetahuan yang dimiliki seseorang terhadap produk atau jasa yang diperolehnya, yaitu semakin banyak informasi yang dimiliki seseorang, seperti suatu produk atau jasa itu mempunyai manfaat positif baginya maka kecenderungan WTP akan semakin tinggi.

Beberapa pendekatan yang digunakan dalam penghitungan WTP untuk menghitung peningkatan atau kemunduran kondisi lingkungan adalah:

1) Menghitung biaya yang bersedia dikeluarkan oleh individu untuk mengurangi dampak negatif pada lingkungan karena adanya suatu kegiatan pembangunan.

2) Menghitung pengurangan nilai atau harga dari suatu barang akibat semakin menurunnya kualitas lingkungan.

3) Melalui suatu survei untuk menentukan tingkat kesediaan masyarakat untuk membayar dalam rangka mengurangi dampak negatif lingkungan atau mendapatkan lingkungan yang lebih baik.

Penghitungan WTP dapat dilakukan secara tidak langsung (indirect method) yaitu penghitungan terhadap nilai penurunan kualitas lingkungan yang telah terjadi dan secara langsung (direct method) dengan melakukan survei pada rumahtangga-rumahtangga pada kawasan tertentu. Salah satu penilaian barang dan jasa lingkungan secara langsung adalah Metode Valuasi Kontigensi (Contigent Valuation Method).
Pendekatan yang tepat untuk memperkirakan ketersediaan membayar disebut metode "contigent valuation" yang didasarkan pada ide sederhana bahwa jika ingin diketahui berapa yang bersedia dikeluarkan oleh orang untuk mencapai kondisi lingkungan tertentu, dapat langsung ditanyakan kepada mereka.

Contingent Valuation Method (CVM) salah satu teknik untuk menilai kualitas lingkungan dari segi manfaat. Menurut Yakin (1997) metode ini digunakan untuk menanyakan kepada responden tentang nilai/harga yang mereka berikan terhadap komoditi yang tidak memiliki pasar seperti barang lingkungan jika pasarnya betul-betul tersedia atau jika ada cara-cara pembayaran lain seperti pajak diterapkan.

CVM pertama kali diperkenalkan oleh Davis pada tahun 1963. Studi CVM telah digunakan untuk mempelajari banyak faktor lingkungan seperti kualitas udara, nilai keindahan alam, kualitas kondisi pantai, perlindungan spesies liar, kepadatan populasi alam liar. Namun pada kenyataannya CVM digunakan untuk halhal diluar permasalahan lingkungan seperti nilai program pengurangan risiko serangan jantung, nilai informasi harga supermarket dan sebagainya.

Beberapa tahapan yang diperlukan dalam analisis CVM :

1) Identifikasi dan deskripsi karakteristik kualitas lingkungan yang akan dievaluasi.

2) Metode identifikasi responden yang dipakai, termasuk prosedur sampling yang digunakan untuk memilih responden.

3) Perancangan dan penerapan kuesioner survei melalui pendekatan personal, telepon atau wawancara lewat surat ataupun Focus Group Discussion (FGD).

4) Analisis hasil dan penggabungan tanggapan individual untuk memperkirakan nilai dari sebuah kelompok masyarakat yang mengalami perubahan lingkungan. 
Dari beberapa studi mengenai menunjukkan bahwa metode ini memiliki beberapa keunggulan dari penggunaannya, antara lain:

1) Sifatnya yang fleksibel dan dapat diterapkan pada beragam kekayaan lingkungan, tidak terbatas pada benda atau kekayaan alam yang terukur secara nyata di pasar saja.

2) Dapat diaplikasikan pada semua kondisi dan memiliki dua hal penting, yaitu seringkali menjadi hanya satusatunya teknik untuk mengestimasi manfaat dan dapat diaplikasikan pada beberapa konteks kebijakan lingkungan.

3) Dapat digunakan dalam berbagai macam penilaian barang-barang lingkungan.

4) Dibandingkan dengan teknik penilaian yang lain, CVM memiliki kemampuan untuk mengestimasi nilai non pengguna. Dengan CVM seseorang mungkin dapat mengukur utilitas dari penggunaan barang lingkungan bahkan jika digunakan secara langsung.

5) Kapasitas CVM dapat menduga nilai non pengguna (non-user).

6) Responden dapat dipisahkan ke dalam kelompok pengguna dan non pengguna sesuai dengan informasi yang didapatkan dari kegiatan wawancara sehingga memungkinkan penghitungan nilai tawaran pengguna dan non pengguna secara terpisah.

Menurut Hanley dan Spash (1993), keterbatasan utama dari penggunaan CVM adalah timbulnya bias, yang terjadi jika penggunaan CVM timbul nilai WTP/WTA yang lebih tinggi atau sebaliknya dari nilai yang sebenarnya. Bias tersebut dapat disebabkan oleh:

1) Bias strategi (strategic bias), yaitu bias yang terjadi karena barang lingkungan memiliki sifat "nonexcludability" dalam pemanfaatannya sehingga timbulnya responden yang bertindak sebagai free-rider dan tidak jujur dalam memberikan informasi.
2) Bias rancangan (design bias), yaitu mencakup cara informasi disajikan, instruksi yang diberikan, format pertanyaan dan jumlah serta tipe informasi yang disajikan kepada responden.

3) Bias yang berhubungan dengan kondisi kejiwaan responden (mental account bias), yang terkait dengan langkah proses pembuatan keputusan seorang individu dalam memutuskan seberapa besar pendapatan, kekayaan dan waktunya dihabiskan untuk barang lingkungan tertentu pada waktu tertentu.

4) Kesalahan pasar hipotetis (hypothetical market error), terjadi jika fakta yang ditanyakan kepada responden dalam pasar hipotesis membuat tanggapan responden berbeda dengan konsep yang diinginkan peneliti sehingga nilai WTP yang dihasilkan menjadi berbeda dengan nilai sesungguhnya.

\section{Analisis Finansial dan Kelayakan Investasi}

Analisis finansial berkaitan erat dengan penerimaan (revenue) yang akan dihasilkan dari suatu kegiatan. Analisis tersebut juga sering dipergunakan oleh pihak Bank sebagai pihak pemberi pinjaman. Menurut Kunarjo (2002) seperti yang dikutip oleh Mintarti (2008), untuk mengetahui secara komprehensif tentang kinerja layak atau tidaknya suatu aktivitas proyek maka dikembangkan berbagai kriteria yang pada dasarnya membandingkan antara biaya dan manfaat atas dasar suatu tingkat harga umum tetap yang diperoleh proyek dengan menggunakan nilai sekarang (present value) yag telah didiskonto selama umur proyek tersebut.

Beberapa metode yang popular untuk menganalisis suatu kegiatan antara lain Analisis Net Present Value (NPV), Internal Rate of Return (IRR), dan Analisis Benefit Cost Ratio (B/C Ratio). Ketiga analisis tersebut menggunakan pendekatan 
nilai uang pada periode awal, yaitu periode dimulainya kegiatan. Menurut Kunarjo (2002), semua arus uang baik yang merupakan pengeluaran maupun pendapatan kegiatan diukur dengan nilai uang pada waktu kegiatan dimulai karena hal ini disebabkan pengaruh tingkat bunga maupun inflasi.

\section{Analisis Perumusan Kebijakan dengan Proses Hierarki Analitik (AHP)}

Proses Hierarki Analitik (AHP) pertama kali dikembangkan oleh Thomas L. Saaty pada tahun 1970-an. AHP pada dasarnya didesain untuk menangkap secara rasional persepsi orang yang berhubungan erat dengan permasalahan tertentu melalui prosedur yang didesain untuk sampai pada skala preferensi diantara berbagai set alternatif. Dalam perkembangannya, AHP tidak hanya digunakan untuk menentukan prioritas pilihan-pilihan dengan banyak kriteria, tetapi penerapannya telah meluas sebagai model alternatif untuk menyelesaikan bermacam-macam masalah seperti memilih portofolio, analisis manfaat biaya, peramalan dan lain-lain. Pendeknya AHP menawarkan penyelesaian masalah yang multiobjectives dan multicriterias. Hal ini dimungkinkan karena AHP cukup mengandalkan intuisi sebagai input utamanya, namun intuisi harus datang dari pengambilan keputusan dengan cukup informasi dan memahami masalah akan keputusan yang sedang dihadapi.

Pada dasarnya AHP adalah suatu teori tentang pengukuran. AHP digunakan untuk menemukan skala rasio baik dari perbandingan pasangan yang diskrit maupun kontinu. Perbandinganperbandingan ini dapat diambil dari ukuran aktual atau dari suatu skala dasar yang mencerminkan kekuatan perasaan dan preferensi relatif. AHP memiliki perhatian khusus tentang penyimpangan dari konsistensi, pengukuran dan pada ketergantungan didalam serta diantara kelompok elemen strukturnya.

Menurut Saaty (1991), untuk menyelesaikan persoalan dengan Proses Hirarki Analitik (AHP) ada beberapa prinsip yang harus dipahami, antara lain: penentuan hirarki, penilaian komparatif, penentuan prioritas, dan konsistensi logis.

\section{Kerangka Pemikiran}

Menurut Rapid Appraisal Survey, Kota Depok merupakan kota yang memiliki cukup banyak sumberdaya alam, salah satunya adalah situ atau danau yang berjumlah 30 buah dan tersebar di penjuru kota (Bapeda Kota Depok, 2001). Situ yang ada belum sepenuhnya dikelola dan dimanfaatkan secara maksimal. Situ Pengasinan merupakan salah satu situ yang ada di Kota Depok yang paling memungkinkan dikembangkan menjadi kawasan wisata dengan konsep one stop recreation. Lingkungan alam yang masih lestari serta letak yang strategis di daerah perbatasan Kota Depok dan Kabupaten Bogor diduga menjadi salah satu nilai tambah untuk dikembangkan lebih lanjut.

Potensi wisata yang dimiliki Situ Pengasinan masih belum tergarap seluruhnya. Saat ini sangat jarang dijumpai situ/danau dengan kondisi yang masih alami seperti Situ Pengasinan. Jika hal tersebut dikombinasikan dengan kegiatan wisata lain seperti outbound, wisata kuliner tepi danau serta wisata lainnya, maka diduga akan membawa pengaruh baik terutama terhadap peningkatan ekonomi masyarakat sekitar serta penerimaan asli daerah dari sektor pariwisata. Kerangka pemikiran dalam kajian ini dapat dilihat pada Gambar 2. 


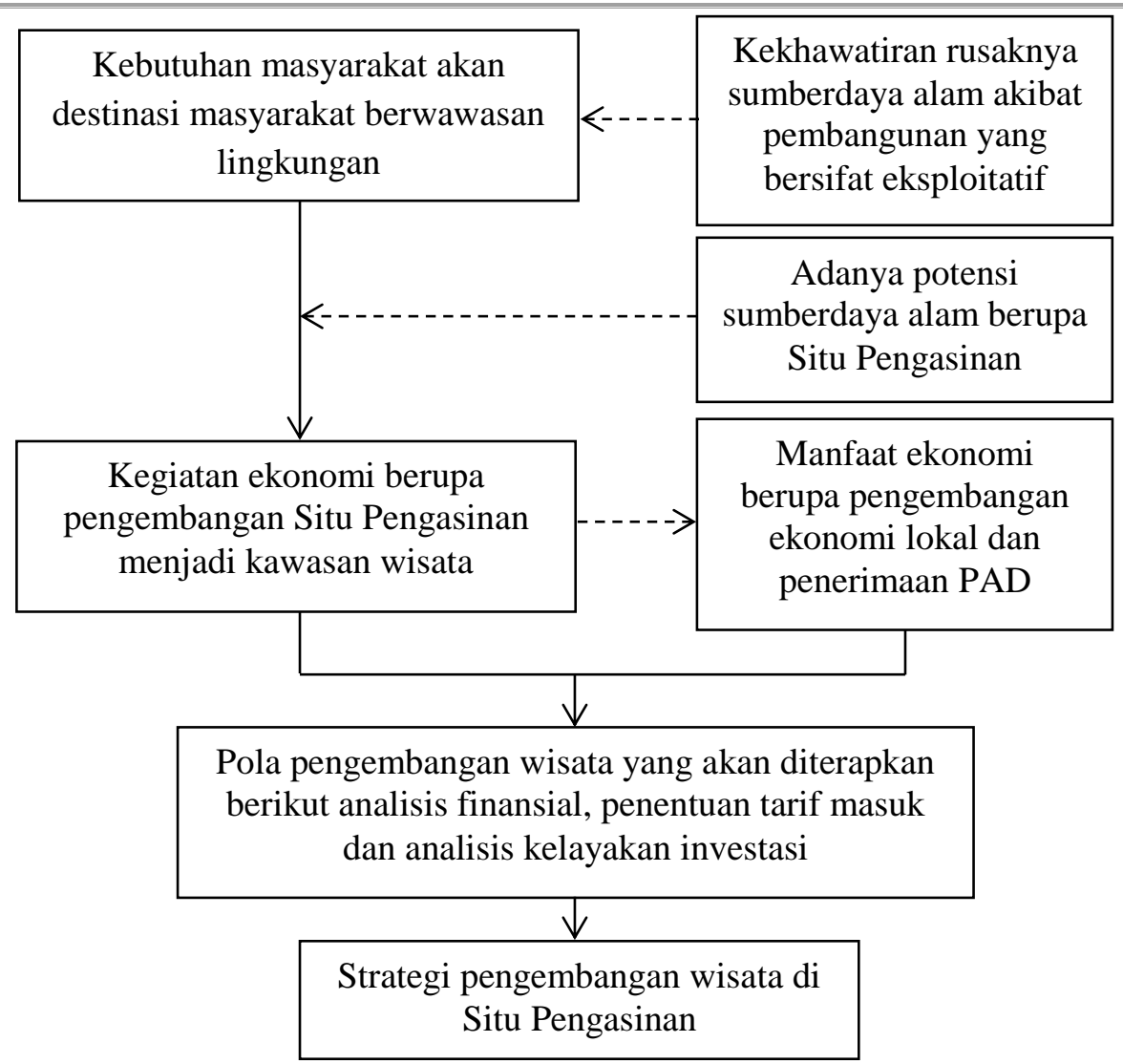

Gambar 2. Kerangka Pemikiran Kajian

\section{METODE PENELITIAN}

\section{Lokasi dan Waktu Penelitian}

Kajian ini dilakukan di Situ Pengasinan, Kota Depok. Pemilihan lokasi kajian didasarkan pada pertimbangan kondisi eksisting situ yang lebih baik dari situ-situ lain di Depok, serta lingkungan sekitar situ yang masih alami dan asri. Situ Pengasinan berada di Bagian Wilayah Kota Sawangan dan dalam perencanaan Kasiba/Lisiba akan dikembangkan menjadi RTH alami serta kawasan wisata dengan luasan 56,9 ha. Kajian dilaksanakan selama tiga bulan, mulai Bulan Januari sampai dengan Maret 2009.

\section{Jenis dan Sumber Data}

Dua jenis data yang dipergunakan dalam kajian ini yaitu data primer dan data sekunder. Data primer diperoleh dari wawancara atau survei terhadap pengunjung situ dan pihak pemerintah daerah (Kantor Pariwisata Seni dan
Budaya Kota Depok, Bapeda Kota Depok, Dinas Bina Marga dan SDA Kota Depok, DPRD Kota Depok). Data primer yang dikumpulkan meliputi persepsi responden terhadap pengembangan wisata Situ Pengasinan dan kesediaan untuk membayar serta besarnya nilai Willingness to Pay (WTP) jika diberlakukan tiket masuk kawasan wisata. Data primer juga digunakan untuk merumuskan strategi dalam pengembangan wisata di Situ Pengasinan dengan Analisis Hirarki Proses (AHP). Data sekunder diperoleh dari beberapa instansi seperti dari Kantor Pariwisata Seni dan Budaya, Bapeda dan BPS serta beberapa literatur, hasil kajian sejenis dan informasi lainnya berhubungan dengan topik kajian.

\section{Metode Analisis}

Metode analisis pada kajian ini terdiri dari enam tahapan, yaitu:

1. Analisis finansial pengembangan Situ Pengasinan yang terdiri dari analisis struktur biaya dan metode penyusutan. 
2. Analisis kesediaan membayar menggunakan regresi logistik.

3. Willingness to Pay responden terhadap tarif masuk kawasan wisata yang terdiri dari metode pendugaan besarnya nilai WTP (metode pertanyaan terbuka) dan penentuan WTP dengan menggunakan CVM.

4. Analisis faktor-faktor yang mempengaruhi besarnya nilai WTP responden menggunakan regresi linier.

5. Analisis kelayakan investasi yang terdiri dari analisis penerimaan, Net Present Value (NPV), Internal Rate of Return (IRR), Net Benefit Cost Ratio (Net B/C), Payback Period (PP), dan analisis switching value.

6. Metode perancangan program dengan menggunakan analisis Analytical Hierarchy Process (AHP).

\section{HASIL DAN PEMBAHASAN}

\section{Persepsi Responden tentang Objek Wisata Situ Pengasinan}

Persepsi responden yang diamati dalam kajian ini meliputi persepsi terhadap pengetahuan tahu atau tidaknya manfaat situ, pengetahuan akan manfaat situ, kegiatan yang dilakukan di Situ Pengasinan, motivasi mengunjungi Situ Pengasinan, kondisi jalan, kemudahan mencapai lokasi, keindahan alam, fasilitas pengunjung, kondisi keamanan, kebersihan, pencemaran air, kenyamanan di Situ Pengasinan, dan Pengembangan Situ Pengasinan.

Sebanyak 95 persen responden telah mengetahui manfaat situ, sebanyak 26 persen responden menjawab manfaat situ sebagai pengendali banjir dan aliran air dan 23 persen lainnya mengatakan manfaat situ sebagai tempat rekreasi atau wisata. Kegiatan utama yang dilakukan responden ketika berkunjung ke Situ Pengasinan adalah wisata air dengan bentuk kegiatan sepeda air atau berperahu mengitari situ (64\%). Sebanyak 39 persen responden datang ke situ dengan motivasi untuk rekreasi.
Sebanyak 54 persen responden menyatakan bahwa kondisi jalan menuju Situ Pengasinan cukup baik dan sebanyak 56 persen responden berpendapat bahwa lokasi Situ Pengasinan mudah dicapai dengan kendaraan pribadi. Selanjutnya, sebanyak 56 persen responden berpendapat bahwa kondisi alam Situ Pengasinan cukup indah sehingga situ tersebut layak untuk dikembangkan menjadi destinasi wisata. Namun sebanyak 80 persen responden berpendapat bahwa fasilitas yang ada di Situ Pengasinan kurang lengkap. Sebanyak 76 persen responden berpendapat Situ Pengasinan cukup aman untuk dijadikan destinasi wisata, 80 persen responden berpendapat Situ Pengasinan sudah cukup bersih. Namun sebanyak 51 persen responden berpendapat bahwa Situ Pengasinan mengalami masalah pencemaran air dengan tingkat sedang dan 44 persen responden berpendapat air di Situ Pengasinan tidak mengalami masalah pencemaran.

Sebanyak 69 persen responden berpendapat bahwa Situ Pengasinan cukup nyaman untuk dijadikan destinasi wisata dan hanya 2 persen responden berpendapat tidak nyaman. Sebanyak 98 persen responden setuju dengan rencana pengembangan Situ Pengasinan menjadi kawasan wisata dengan rincian 56 persen responden memilih konsep pengembangan kawasan wisata yang memuat berbagai atraksi wisata seperti wisata alam, wisata kuliner, wisata budaya,dan wisata agro.

\section{Analisis Finansial}

Jenis atraksi dan sarana prasarana yang direncanakan akan dibangun adalah outbound, trampoline, waterball, penyewaan ATV, sepeda air, perahu wisata, resort, kampung wisata, waterpark, foodcourt, bangunan utama dan penunjang, lapangan parkir serta sentra tanaman hias. Berdasarkan asumsi tersebut, kegiatan pengembangan wisata di Situ Pengasinan membutuhkan investasi Rp 6.045.000.000 yang terdiri atas biaya legalitas, biaya pembangunan infrastuktur serta biaya pembelian peralatan. Total nilai sisa dari 
keseluruhan investasi tersebut $\mathrm{Rp}$ 284.500.000 dengan nilai penyusutan per tahun Rp 387.283.333. Total biaya tetap kegiatan pengembangan situ sebesar $\mathrm{Rp}$ 1.369.200.000 sedangkan total biaya variabel yang meliputi biaya listrik dan biaya bahan bakar mencapai $\mathrm{Rp}$ 250.000.000.

\section{Analisis Kesediaan Membayar Atau Ketidaksediaan Responden Membayar Tarif Masuk Kawasan Wisata}

Dari hasil penyebaran kuesioner kepada 41 responden, didapat sebanyak 21 responden $(51 \%)$ bersedia membayar tarif masuk kawasan wisata, sedangkan 20 responden (49\%) tidak bersedia membayar tarif masuk kawasan wisata. Variabelvariabel penjelas yang digunakan dalam model logit terdiri atas lima variabel kontinyu dan dua variabel dummy. Variabel kontinyu terdiri atas usia, tingkat pendidikan, tingkat pendapatan, frekuensi berkunjung dan jarak ke lokasi. Sedangkan variabel dummy terdiri dari jenis kelamin dan jenis pekerjaan. Persamaan regresi logistik untuk faktor-faktor yang mempengaruhi kesediaan membayar tarif masuk kawasan wisata:

Kesediaan membayar $=-5,401+1,219$ Jenis kelamin $+0,051$ Umur $+0,299$ Lama Pendidikan - 3,623 Pekerjaan $+0,000$ Pendapatan - 0,007 Jarak lokasi $+0,134$ Frekuensi Berkunjung $+€ \mathrm{i}$

Variabel lama pendidikan dan pendapatan berkorelasi positif, sedangkan variabel pekerjaan berkorelasi negatif dengan kesediaan membayar tarif masuk. Korelasi negatif variabel pekerjaan menunjukkan tidak bersedianya untuk membayar bagi responden yang bekerja sebagai non PNS.

\section{Analisis Besarnya WTP Responden Terhadap Tarif Masuk Kawasan Wisata}

Berdasarkan hasil kuesioner, 71,43 persen responden memilih untuk membayar tarif masuk dengan nilai minimum sebesar Rp 5.000,-/orang dan 9,5 persen responden memilih untuk membayar tarif masuk kawasan dengan nilai maksimum $\mathrm{Rp}$ 25.000,-/orang. Dipilihnya tarif masuk $\mathrm{Rp}$ 5.000,-/orang karena responden harus mengeluarkan sejumlah uang tambahan untuk menikmati atraksi wisata yang disediakan. Dengan nilai tarif minimum maka peluang untuk menikmati berbagai atraksi yang ada cukup besar karena pengeluaran tidak sepenuhnya tersedot pada tarif masuk kawasan wisata.

\section{Analisis $\quad$ Faktor-faktor $\quad$ Yang Mempengaruhi WTP}

Variabel penjelas yang digunakan dalam penelitian ini terdiri dari lima variabel kontinyu (usia, tingkat pendidikan, tingkat pendapatan, frekuensi berkunjung dan jarak ke lokasi) dan dua variabel dummy (jenis kelamin dan jenis pekerjaan). Persamaan hasil regresi linier untuk faktor-faktor yang mempengaruhi besarnya nilai WTP responden untuk tarif masuk kawasan wisata adalah:

$\mathrm{WTP}=2651+1197$ Jenis Kelamin -161 Umur $+137,6$ Pendidikan +46 Pekerjaan + 99,92 Pendapatan + 4688 Frekuensi berkunjung $+8,49$ Jarak lokasi

Hasil analisis regresi menunjukkan bahwa variabel penjelas yang signifikan (nyata) pada alpha 5 persen yaitu Pendapatan dan pada alpha 10 persen pendapatan dan frekuensi berkunjung. Dari model tersebut dapat diperoleh intepretasi bahwa semakin tinggi pendapatan yang diterima seseorang maka besarnya nilai WTP yang akan dibayarkan menjadi 2,73 kali lebih besar dari responden dengan pendapatan lebih rendah, dengan tarif masuk lebih besar dari Rp 7.309,52/orang. 
Dari hasil uji regresi didapat interpretasi semakin sering seseorang datang berkunjung maka besarnya nilai WTP yang akan dibayarkan 1,89 kali lebih besar dari Rp 7.309,52/orang terlebih jika responden tersebut yakin bahwa pemerintah kota serius menggarap pengembangan kawasan wisata yang direncanakan.

\section{Analisis Kelayakan Investasi}

Analisis kelayakan investasi akan menghitung besarnya penerimaan serta kelayakan kegiatan melalui pendekatan IRR, NPV, B/C ratio serta payback period atau jangka waktu pengembalian modal untuk dua skenario pengembangan yang telah disiapkan, yakni dengan pemberlakuan tarif masuk kawasan dan tanpa pemberlakuan tarif masuk kawasan. Discount rate yang digunakan dalam perhitungan adalah 14 persen.

Berdasarkan hasil perhitungan analisis kelayakan investasi dengan pemberlakuan tarif, didapatkan nilai NPV sebesar Rp 74.343.698.556, nilai IRR sebesar 26,33 persen, nilai $\mathrm{B} / \mathrm{C}$ ratio 1,66 dengan payback period atau periode pengembalian investasi 7,26 tahun sehingga kegiatan ini layak secara finansial dan dapat dilakukan. Sedangkan pada hasil perhitungan analisis kelayakan investasi tanpa pemberlakuan tarif didapatkan nilai NPV sebesar Rp 57.259.761.259, nilai IRR sebesar 14,66 persen, nilai $\mathrm{B} / \mathrm{C}$ ratio 1,47 , serta payback period 11,18 tahun. Meskipun hasil tersebut menunjukkan bahwa kegiatan layak untuk dilaksanakan, namun jangka pengembalian investasi dari kegiatan pengembangan wisata tanpa pemberlakuan tarif masuk kawasan dua tahun lebih lama jika dibandingkan rencana pengembangan dengan skenario pemberlakuan tarif masuk kawasan. Selanjutnya, hasil analisa switching value menunjukkan bahwa kegiatan pengembangan wisata tanpa pemberlakuan tarif masuk sangat sensitif terhadap penurunan jumlah pengunjung dimana penurunan jumlah pengunjung sebanyak
10 persen menyebabkan jangka waktu pengembalian investasi melebihi umur kegiatan meskipun $\mathrm{B} / \mathrm{C}$ ratio lebih dari 1 dan NPV tidak sama dengan 0 .

\section{Strategi Pengembangan Wisata di Situ Pengasinan}

Perancangan program pemilihan strategi pengembangan wisata di Situ Pengasinan dilakukan melalui analisis AHP. Urutan lengkap nilai bobot untuk kriteria serta alternatif kebijakan dapat dilihat pada Gambar 3. Rancangan program strategi yang didapatkan untuk pengembangan wisata di Situ Pengasinan meliputi:

1. Sosialisasi, antara lain dengan melakukan kegiatan FGD (Forum Group Discussion) antara masyarakat, pemerintah kota dan swasta serta promosi mengenai wisata melalui seminar/workshop/penyebaran pamflet untuk menarik minat pengunjung.

2. Pemberdayaan masyarakat melalui kegiatan pembentukan dewan budaya untuk melestarikan budaya atau tradisi lokal, pembukaan peluang partisipasi masyarakat, dan melakukan pelatihan kewirausahaan skala kecil dan menengah.

3. Pembangunan sarana dan prasarana kawasan wisata dengan menggandeng investor melalui kegiatan penyusunan profil kelayakan investasi, promosi, pemilihan investor melalui tender atau lelang, membentuk tim yang bertugas mengevaluasi perjanjian kerjasama.

4. Peningkatan infrastruktur melalui peningkatan pelayanan transportasi dan pengelolaan lingkungan hidup.

5. Peningkatan kebijakan atau dukungan kelembagaan melalui kegiatan public hearing antara pihak eksekutif dengan legislatif, penerbitan SK Penetapan Program Kasiba/Lisiba Sawangan, serta pembuatan MoU tentang pelaksanaan Kasiba berikut turunan pola kerjasama yang lebih spesifik. 


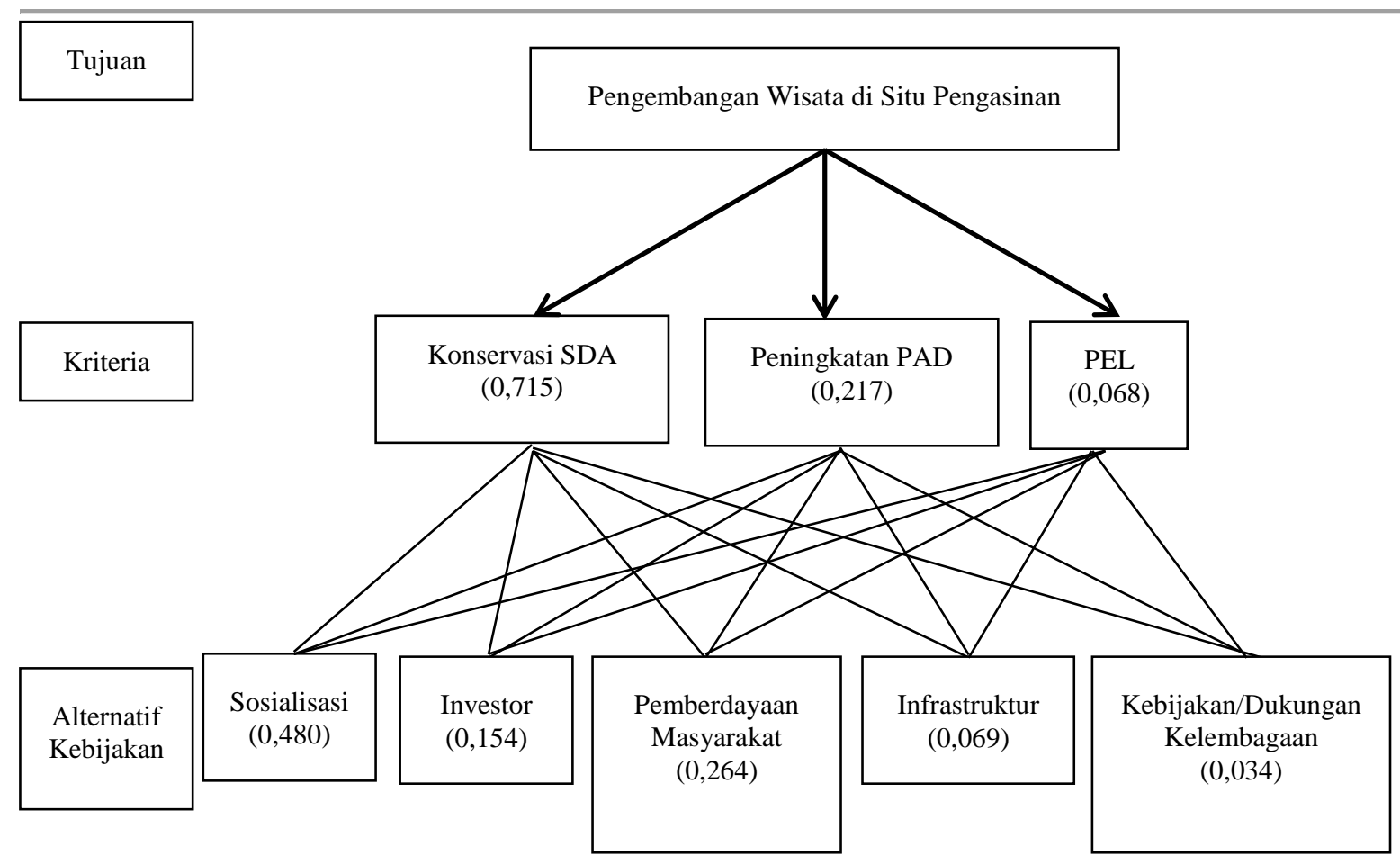

Gambar 3. Nilai Bobot Hirarki AHP Pengembangan Wisata di Situ Pengasinan

\section{KESIMPULAN DAN SARAN}

\section{Kesimpulan}

Berdasarkan hasil kajian mengenai strategi pengembangan wisata di Situ Pengasinan Kota Depok, terdapat beberapa kesimpulan yaitu:

1. Secara umum responden mendukung rencana pengembangan Situ Pengasinan sebagai kawasan wisata dengan konsep "one stop recreation" dengan tidak mengganggu fungsi utama situ sebagai daerah konservasi air permukaan.

2. Investasi sebesar Rp 6,045 milyar dibutuhkan untuk mendanai kegiatan pengembangan wisata Situ Pengasianan berupa pembangunan sarana prasarana dan atraksi wisata.

3. Responden bersedia membayar tarif masuk sebesar Rp 7.309,52,-/orang jika skenario pemberlakuan tarif dilakukan.

4. Kegiatan pengembangan wisata di Situ Pengasinan secara finansial layak untuk dilakukan, namun, analisis switching value menunjukkan bahwa kegiatan pengembangan wisata dengan skenario tanpa pemberlakuan tarif masuk sangat sensitif terhadap penurunan jumlah pengunjung.

5. Rancangan program strategi pengembangan wisata Situ Pengasinan meliputi sosialisasi, pemberdayaan masyarakat, pembangunan sarana dan prasarana kawasan wisata, peningkatan infrastruktur, serta peningkatan kebijakan atau dukungan kelembagaan.

\section{Saran}

Berdasarkan hasil analisis dalam pengembangan wisata di Situ Pengasinan Kota Depok, didapatkan rekomendasi kebijakan yang meliputi melakukan penyesuaian tata ruang eksisting sesuai dengan masterplan Kasiba/Lisiba wilayah Sawangan melalui revisi RTRW Kota Depok, mensinergikan koordinasi antar OPD yang terkait dengan pengembangan wisata, menciptakan iklim investasi yang menarik dan penjaminan keamanan, melakukan pengembangan atraksi wisata yang lebih menarik dari yang direncanakan, serta merekomendasikan kepada Pemerintah Kota Depok untuk memperpanjang jangka waktu kerjasama, 
membentuk BUMD yang membidangi pengelolaan wisata, memberlakukan tarif masuk kawasan, lebih mengembangkan ekonomi lokal daripada PAD dalam rangka meningkatkan kesejahteraan masyarakat, dan untuk segera menjalankan rancangan program berikut strategi yang telah dibuat demi terealisasinya pengembangan wisata di Situ Pengasinan.

\section{DAFTAR PUSTAKA}

Bapeda Kota Depok. 2001. Rapid Appraisal Survey Situ-Situ di Kota Depok. Depok: Bapeda Kota Depok.

Dahuri R. J, Rais dan S. P Ginting.1996. Pengelolaan Sumberdaya Wilayah Pesisir dan Lautan Secara Terpadu. Jakarta: Pradnya Paramita.

Dahuri, R. 2003. Paradigma Baru Pembangunan Indonesia Berbasis Kelautan, Orasi Ilmiah: Guru Besar Tetap Bidang Pengelolaan Sumberdaya Pesisir dan Lautan. Bogor: Fakultas Perikanan dan Ilmu Kelautan, Institut Pertanian Bogor.

Dewi, Rachma. 2004. Analisis Kemauan Membayar Pasien (WTP) dihubungkan dengan Karakteristik Kemampuan Membayar dan Persepsi Pasien Terhadap Mutu dan Manfaat Pelayanan Puskesmas Sukmajaya Kota Depok Provinsi Jawa Barat [tesis]. Jakarta: Program Pascasarjana, Universitas Indonesia.

Kantor Pariwisata Seni dan Budaya Kota Depok. 2006. Rencana Strategis 2006-2011. Depok: Kantor Pariwisata Seni dan Budaya Kota Depok.

Karyono, A.H. 1997. Kepariwisataan. Jakarta: Gramedia Widiasarana Indonesia.

Kunarjo. 2002. Perencanaan dan Pengendalian Program
Berbasis Komoditas Kelapa di kabupaten Pacitan [tesis]. Bogor : Program Pascasarjana, Institut Pertanian Bogor.

Putri EIK, Ismail A, Buitenzorgy M, Wijayanti P. 2007. Modul Kuliah Ekonomi Lingkungan. Bogor: Fakultas Ekonomi dan Manajemen, Institut Pertanian Bogor.

Saaty, T.L. 1991. Pengambilan Keputusan Bagi Para Pemimpin (Proses Hirarki Analitik untuk Pengambilan Keputusan dalam Situasi Yang Kompleks). Jakarta : Pustaka Binaman Pressindo.

Saifullah. 2000. Kajian Pengembangan Pariwisata Bahari dan Kontribusinya Pada Kesejahteraan Masyarakat Pesisir di Pulau Weh (Sabang). [tesis]. Bogor: Program Pascasarjana, Institut Pertanian Bogor.

Suryadiputra, 2005. Kodisi Situ-Situ di Jabotabek. Prosiding Pertemuan Penyusunan Pedoman Kelembagaan Pengelolaan Situ di Wilayah Jabodetabek: Jakarta, 19 Agustus 2005.

Yakin, A. 1997. Ekonomi Sumberdaya dan Lingkungan. Teori dan Kebijakan Pembangunan Berkelanjutan. Jakarta: Akademika Presindo.

Yoeti, Oka. A. 1999. Ekonomi Pariwisata (introduksi, informasi, dan implementasi). Jakarta: Kompas .
Mintarti, Nana. 2008. Strategi Pengembangan Ekonomi Lokal

